\title{
Geometry of slab, intraslab stress field and its tectonic implication in the Nankai trough, Japan
}

\author{
Jiren $\mathrm{Xu}^{1 *}$ and Yoshiteru Kono ${ }^{2}$ \\ ${ }^{1}$ Deep Sea Research Department, Japan Marine Science and Technology Center (JAMSTEC), Yokosuka 237-0061, Japan \\ ${ }^{2}$ Faculty of Science, Kanazawa University, Kanazawa 920-1192, Japan
}

(Received June 30, 1999; Revised March 29, 2002; Accepted May 12, 2002)

\begin{abstract}
The characteristics of geometry of slabs and the intraslab stress field in the Nankai subduction zone, Japan, were analyzed based on highly accurate hypocentral data and focal mechanism solutions. The results suggest that the shallow seismic zone of the Philippine Sea slab subducts with dip angels between 10 and 22 degrees beneath Shikoku and the Kii peninsula, and between 11 and 40 degrees beneath Kyushu. Two types of seismogenic stress field exist within the slab. The stress field of down-dip compression type can be seen in the slab beneath Shikoku and the Kii peninsula, where the horizontal component of regional compression stress is NNW. On the other hand the stress field of down-dip extension type within the slab is dominant in the region from western Shikoku to Kyushu, where the direction of horizontal compressive stress is near WWN. The existence of the two types of stress field is related to the differences of slab geometry and slab age of the subduciton zone. These properties imply that slab beneath Kyushu (40 Ma) probably is older than that beneath Shikoku and the Kii peninsula (11-20 Ma). The young slab of the oceanic Philippine Sea plate subducts with a shallow angle beneath the Eurasian plate in Shikoku and the Kii peninsula. The subduction has encountered strong resistance there, resulting in a down-dip compression stress field. The down-dip extension stress field may be related to the older slab of the Philippine Sea plate which subducts beneath Kyushu with a steeper dip angle.
\end{abstract}

\section{Introduction}

The Nankai trough, southwest Japan, is one of the typical subduction zones, where the Philippine Sea plate $(\mathrm{PH})$ subducts beneath the Eurasian plate (EU) (Moores and Twiss, 1995). A series of large interplate earthquakes have occurred along the trough at intervals of 100-150 years (Fig. 1). The oldest event recorded in historical documents occurred in A.D. 684 (M8.4, Imamura, 1930). However, no large earthquake $(\mathrm{M}>7.5)$ has occurred along the Nankai trough since the 1946 M8.0 Nankai earthquake. In addition, even medium-size earthquakes (M6.0-7.0) have not occurred for the last about 50 years off Shikoku and the Kii peninsula. Next large earthquakes along the trough perhaps will occur within several dozens of years (Ishibashi, 1980; Ando, 1999).

Mechanisms of great earthquakes, the seismic activity and seismogenic stress field in the Nankai trough region, therefore, have been of great concern to many seismologists (Ando, 1982; Okano et al., 1985). Ishikawa and Ishihara (1997) suggested that the Philippine Sea plate subducting beneath Shikoku was partly split and detached from the rest of the slab, based upon revised hypocentral data by the Japan Meteorological Agency (JMA). Nakamura et al. (1997)

*Present address: Institute of Geology, Chinese Academy of Geological Science, Beijing 100037, China.

Copy right(c) The Society of Geomagnetism and Earth, Planetary and Space Science (SGEPSS); The Seismological Society of Japan; The Volcanological Society of Japan; The Geodetic Society of Japan; The Japanese Society for Planetary Sciences. mapped the leading edge of the Philippine Sea plate in the Nankai area by analyzing seismicity. Kimura and Okano (1994) pointed out that the seismic activities in the Shikoku area characterized two focal depth ranges; one is in the upper crust and another is in the uppermost mantle.

The results of ScS phase observations (Nakanishi, 1980) and P-wave velocity structure obtained by tomographic inversions (Hirahara, 1981; Kamiya, 1991) suggested that the leading edge of the Philippine Sea plate descending from the Nankai trough might have reached the upper mantle beneath the Chugoku district, although few deep earthquakes occurred there. The results from a wide-angle ocean-bottom seismograph (OBS) survey in the western Nankai trough indicated that the subducting oceanic crust could be traced down to $40 \mathrm{~km}$ depth beneath the Shikoku Island (Kodaira et al., 2000).

The previous studies have already provided some constraints on the seismogenic stress field in the Nankai trough. However, the results obtained cannot well explain complex tectonic characteristics of the Nankai trough. In order to understand recurrence intervals and mechanisms of great interplate earthquakes along the Nankai trough, it is necessary to study the regional stress field in this region, especially in and around Shikoku by using highly accurate focal mechanisms. Recently, seismic Networks have been improved in the Nankai trough region, and many microearthquakes have been located with higher accuracy. In this study, we investigate the geometry and stress field of the slab along the Nankai subduction zone. The clear regional characteristics 


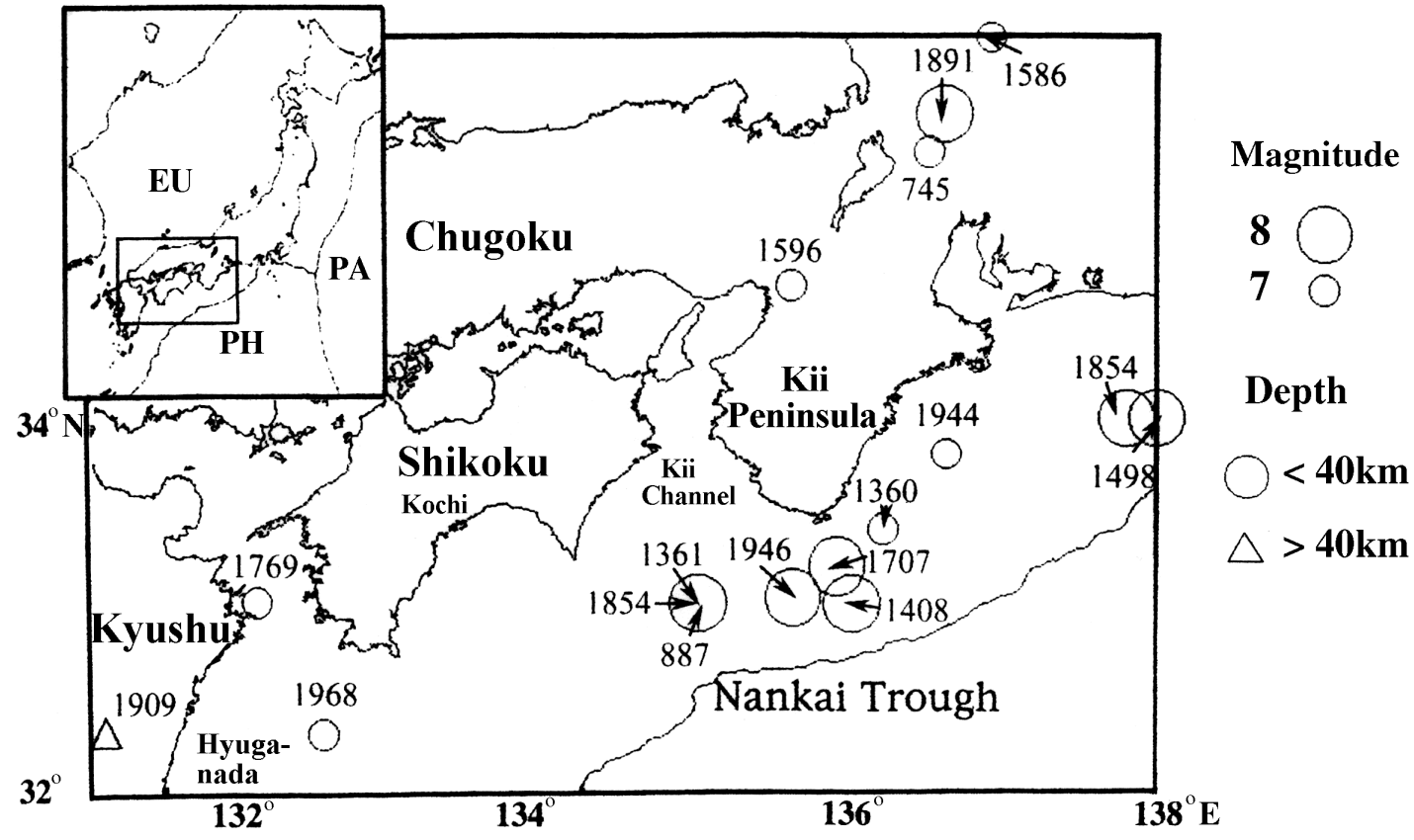

Fig. 1. Epicenters of great earthquakes $(M>7.5)$ along the Nankai trough for the period 745 to 2000 after Usami (1996). The epicenters of historical events were determined based on isoseismal counters reconstructed from historical documents. The left upper figure shows the plate boundaries around the Nankai trough. PH, the Philippine Sea plate; EU, the Eurasian plate, and PA, the Pacific plate.

of the seismogenic stress field and its tectonic implication for the Nankai trough are discussed.

\section{Data}

We used various hypocentral data files: the "Chronological Scientific Tables (Rika Nenpyo, Tokyo Astronomical Observatory, 2000)" for earthquakes occurring before 1884 (National Astronomical Observatory, 1998); Utsu's (1979) catalog for events in 1885-1925; and Japan Meteorological Agency (JMA) Seismological Monthly Bulletins for those in 1926-1998. In addition, we used the Japan University Network Earthquake Catalog Hypocenters File (NECHF) for events in 1985-1992 and the Nankai-SeismicNetwork Earthquake Catalog (NSNEC) for events in 19851992 (Nakamura et al., 1997). The latter file was compiled and edited from various data files with University Networks covering over the Nankai region.

The oldest great earthquakes occurred in 684 (Imamura, 1941), and other great earthquakes occurred in 887, 1096, 1099, 1361, 1498, 1605, 1707, 1854, 1944 and 1946 (e.g. Usami, 1996; Rika Nenpyo, Tokyo Astronomical Observatory, 2000). The locations of great earthquakes in Fig. 1 were determined from isoseismal contours reconstructed from historical documents (Usami, 1996).

The accuracy of hypocenter locations is $20 \mathrm{~km}$ for data from Utsu's catalog (1884-1925), $10 \mathrm{~km}$ for the JMA data and $3 \mathrm{~km}$ for the NECHF data. Kanno et al. (1990) demonstrated the high accurate locations of hypocenters in the NECHF. Errors become greater in general for events occurring outside the observation Networks. The capability differs among the regions. The lower limits of magnitude and accuracy of hypocenter probably fall down in regions outside the observation Networks, especially in offshore regions. We pay mainly attention to seismic zones with high- density hypocenters in the present study, ignoring hypocenter data with isolated distribution or sparse density. A few pseudo-hypocenters, e.g. artificial explosions, may be included within the files, but this does not affect results of the present study because of the scarcity.

In order to clarify the mechanism of great earthquakes in the Nankai subduction zone, it is necessary to investigate characteristics of intraslab stress field and movements of the Philippine Sea plate. It is somewhat difficult to clarify the regional characteristics of the stress field in detail based on the focal mechanism solutions of events $(M>5.0)$ because of the low seismic activity in and around the Nankai subduction zone since the 1946 Nankai earthquake, especially in Shikoku area. Recently, more earthquake focal mechanism solutions including events $(\mathrm{M}>3.0)$ have been obtained for the Nankai region. These solutions are useful for the study of stress field within the slab. In this study, focal mechanism solutions of 543 events $(\mathrm{M}>3.0)$ were used. The solutions of events were selected from the period between 1936 and 1998 , although most of the events occurred after 1975. Focal mechanism solutions for 41 events are selected from CMT solutions of Harvard University and 2 from USGS catalog. Solutions of 347 events are selected from the NSNEC data (Nakamura et al., 1997) and 89 from Tsuboi et al. (1994). Solutions of 64 events are determined in the present analysis.

\section{Geometry of the Philippine Sea Slab Inferred from Seismicity}

Based on results of 3-D velocity inversion, the Philippine Sea plate subducted down to a depth of about $60-70 \mathrm{~km}$ beneath Shikoku and Chugoku, and to about 100-150 km beneath Kyushu (Hirahara, 1981). The leading edge is inferred from the analyses of seismicity to reach a depth of $40 \mathrm{~km}$ 


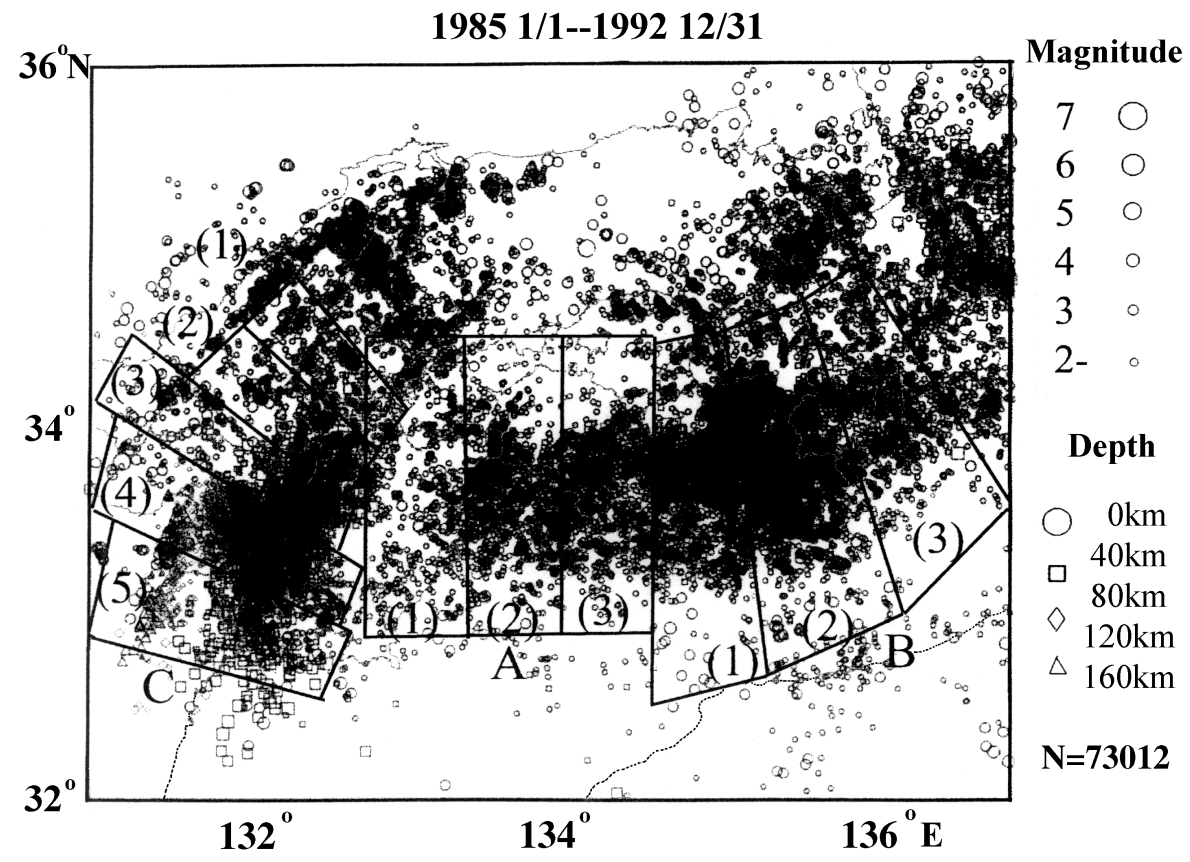

Fig. 2. Epicenters of earthquakes during period of 1985-1992 (M $\geqq 0.0)$. Database is from the Nankai Seismic Network Earthquake Catalog compiled by Nakamura et al. (1997). Regions A, B and C show the Shikoku, the Kii peninsula and the Kyushu regions, respectively.

beneath Shikoku (Kimura and Okano, 1994, 1998; Okano et al., 1983). The focal depths were determined to be about 10-35 km off Shikoku (Kimura and Okano, 1991b). The seismic zone lies at a low angle about 5 degrees from central Shikoku to Chugoku (Miura et al., 1991). The seismic events possibly located in the slab dip about 9 degrees from south to north beneath Shikoku (Kimura and Okano, 1991a), although they interpret these events as "mantle seismic events" instead of slab events. The oceanic crust descends to depths of about $70 \mathrm{~km}$ beneath the Kii peninsula on the basis of analysis of trapped waves within the oceanic crust with a lower P-wave velocity (Hori et al., 1985), suggesting the slab penetrates at least this depth. This coincides with that subcrustal earthquakes penetrate down to about $65-90 \mathrm{~km}$ beneath Kii peninsula (Mizoue et al., 1983), where the slab descends almost westward with a dip of 30 degrees (Watanabe and Maeda, 1990). The seismic zone in the Philippine Sea slab inclined to about $120 \mathrm{~km}$ beneath Kyushu (Mizoue et al., 1983; Yamazaki and Ooida, 1985).

The results related to the geometry of Philippine Sea slab inferred from the seismicity are shown in Figs. 2 and 3. Figure 2 shows the epicenters for events $(M \geqq 0.0)$ from Jan. 1, 1985 to Dec. 31, 1992. Characteristics of seismicity are in detail summarized by zoning the study region into the three areas, (A) Shikoku, (B) the Kii peninsula and (C) Kyushu. Each area is further divided into several sub-areas (Fig. 2). The zonings are carried out based on regional characteristics of seismicity and stress field described below. Figure 3 shows the hypocenter distributions in the vertical sections of all sub-areas of $\mathrm{A}, \mathrm{B}$ and $\mathrm{C}$ regions. On the basis of the geometry of the seismic zones of the Philippine Sea slab, we try to analyze main characteristics features: dip angles and depths of penetration of the slabs along the Nankai trough. Main tectonic characteristics are different among the above three regions.

\subsection{Shikoku area (Region A)}

Profiles 1-3 in Fig. 3(a) show seismic activity beneath Shikoku and its surroundings obtained from the database used in this study. The upper seismic layer shallower than $20 \mathrm{~km}$ shows crustal events; the lower one deeper than about $20 \mathrm{~km}$ may be events in the subducting seismic zone of the Philippine Sea slab. There seems to be a thin aseismic layer between the two seismic zones, which are possibly located artificially at a layer boundary due to hypocenter calculation. The seismic zone in the Philippine Sea slab, dipping about 10 degrees, is very thin in profile 1 , but somewhat thicker in profile 3. Beneath Shikoku, the slab reaches down to about $60 \mathrm{~km}$ depth in the central part of Shikoku as shown in the figure.

\subsection{Kii peninsula (Region B)}

Profiles 1-3 in Fig. 3(b) show seismic activity beneath the Kii peninsula. The upper seismic zone in the crust and the lower intraslab one are clearly seen in the figure. It can be also seen that the dip angles in Fig. 3(b) are steeper than those in Fig. 3(a). In profile 1, the dip angle of the seismic plane is 11 degrees beneath the western Kii peninsula, where the leading edge of the slab reaches about $45 \mathrm{~km}$. The dip angle of the slab gradually changes and reaches 22 degrees beneath the central and eastern Kii peninsula (profiles 2 and 3 ), where the leading edge reaches down to about $80 \mathrm{~km}$ depth.

\subsection{Kyushu (Region C)}

Profiles $1-5$ in Fig. 3(c) show seismic activity beneath Kyushu from north to south. The maximum dip direction of the seismic plane changes NW to NWW, which differs from those in Shikoku and the Kii peninsula. Moreover, the profiles in Fig. 3(c) show that the dip angle of the slab obviously changes from 11 degrees (Profile 2) to 40 degrees (Profile 3). The depths of leading edge of the Philippine Sea slab vary from $60 \mathrm{~km}$ (Profile 2) to $160 \mathrm{~km}$ (Profile 5), gradually. 


\section{$19851 / 1$-- 1992 12/31 N=73012}

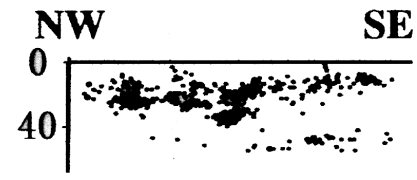

(1)

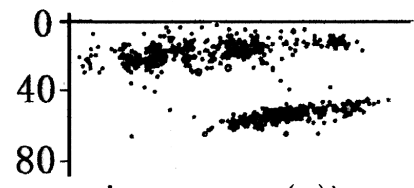

(2)
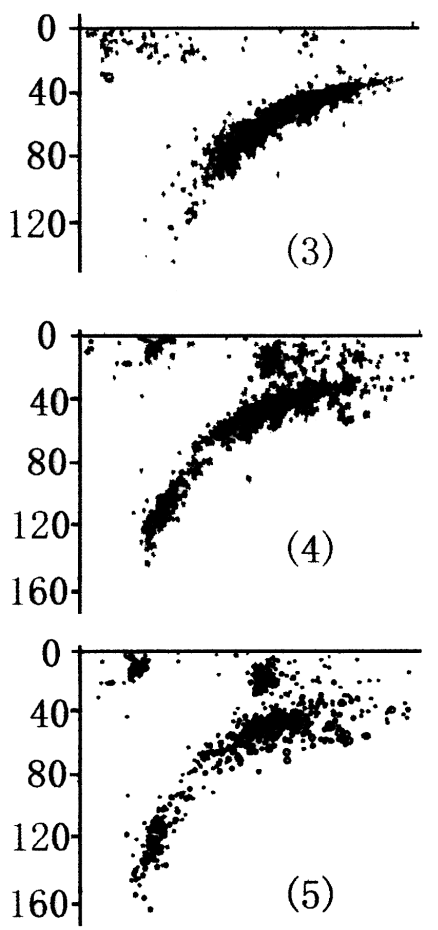
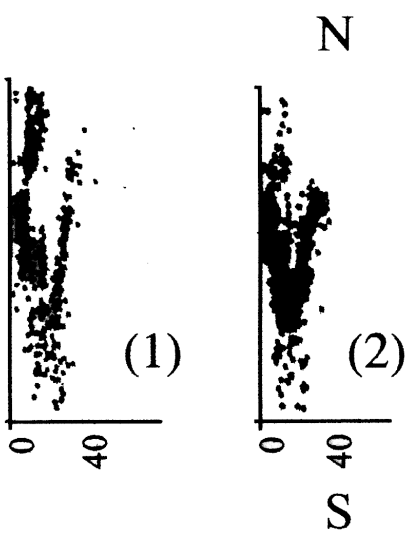

(A) Shikoku

NWN
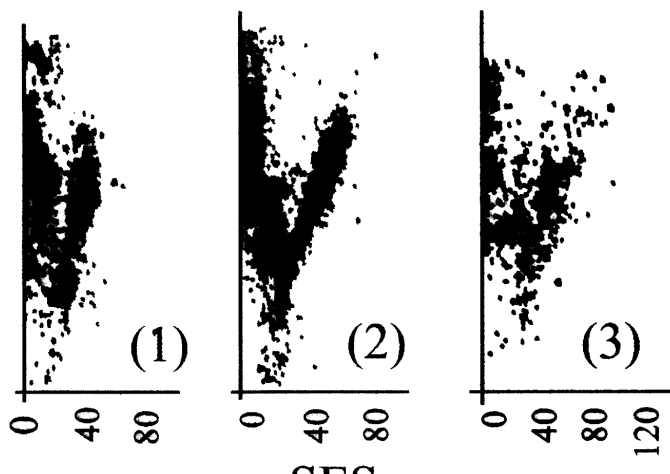

SES

(B) Kii peninsula

(C) Kyushu

Fig. 3. Profiles of distribution of microearthquakes for regions (A) Shikoku, (B) the Kii peninsula and (C) Kyushu in Fig. 2. The database is same as in Fig. 2.

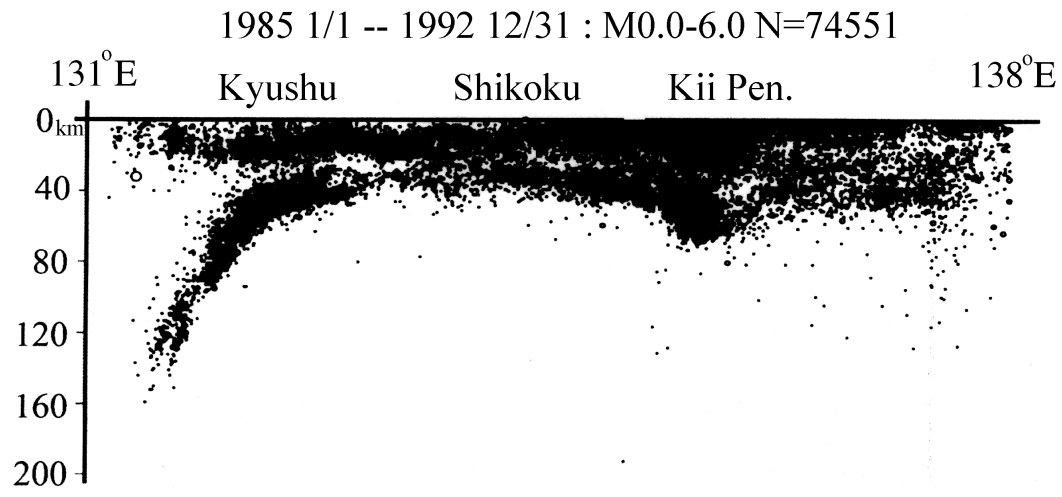

Fig. 4. EW cross section of hypocenters of microearthquakes along the Nankai trough. The database is same as in Fig. 2. 
1936 1/1-1998 12/31 M3-7.5 Depth 0-200km

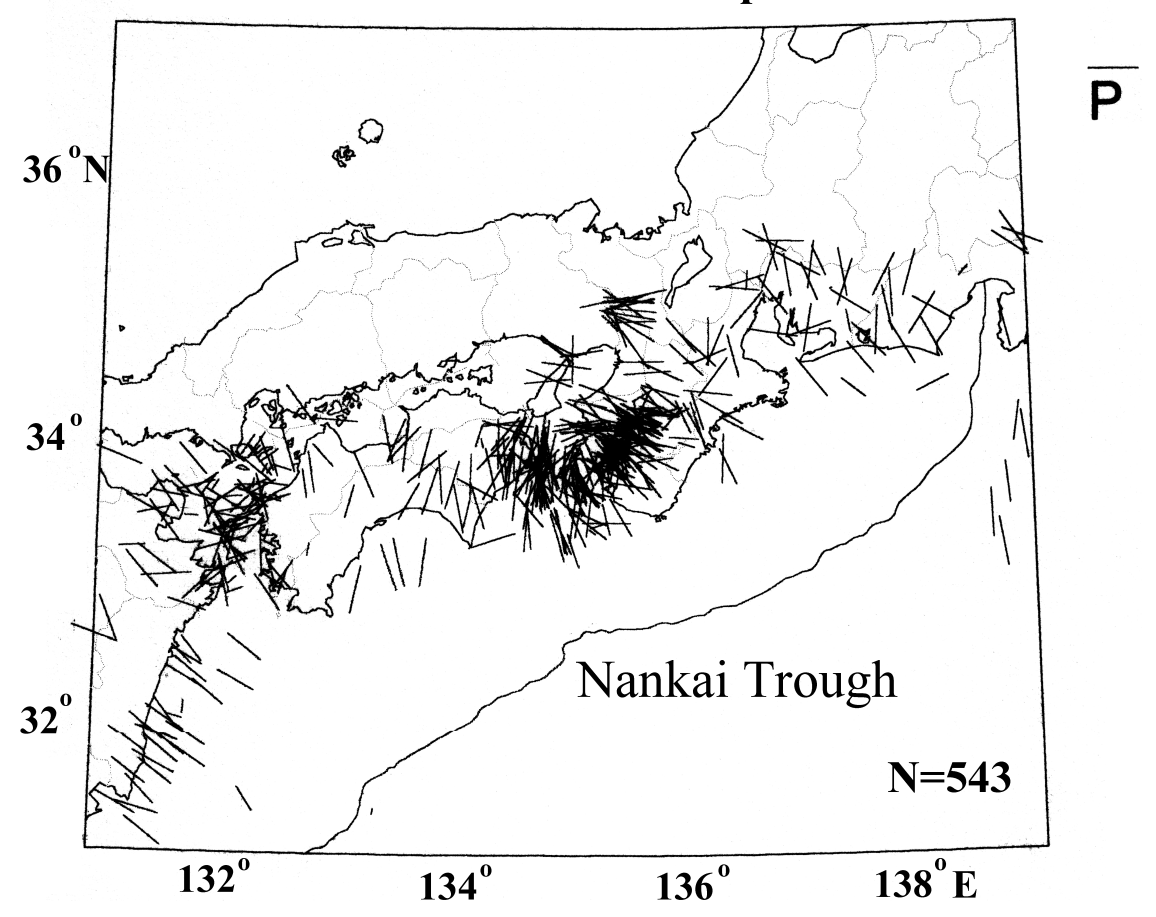

Fig. 5. Horizontal projection of compressional axes (P-axes) obtained from focal mechanism solutions of 543 earthquakes (M $\geqq 3$ ) during 1936-1998 in the Nankai trough.

\subsection{Along-strike slab geometry}

Figure 4 shows the profile along the EW section of hypocentral distribution of earthquakes from the database used in this study. These events are microearthquakes which occurred between latitudes $32-36 \mathrm{~N}$ degrees and longitudes 131-138E degrees during the period from 1985 to 1992 . The figure clearly shows two seismic layers; namely the upper crustal seismic layer and the lower slab seismic layer of the Philippine Sea plate. The bottom of seismicity varies in the E-W profile beneath the Kii peninsula. It can be seen that the lower limit of the seismicity is located at $57 \mathrm{~km}$ depth beneath Kii Channel, $80 \mathrm{~km}$ beneath the central and western part of the Kii peninsula and becomes shallower than $80 \mathrm{~km}$ to the east. This geometry of the slab can be attributed to the relative motions among the Philippine Sea, the Eurasian and the Pacific plates.

\section{Regional Characteristics of Intraslab Stress Field of Philippine Sea Plate}

Horizontal projections of compressional axes (P-axes) and extensional axes (T-axes) of focal mechanism solutions of the 543 slab earthquakes $(\mathrm{M} \geqq 3.0)$ are shown in Figs. 5 and 6 , respectively. The study region is zoned into three areas to analyze characteristics of regional seismogenic stress field and tectonic movements of the plate as shown in Fig. 7: regions A, B and C for Shikoku, Kii and western ShikokuKyushu, respectively. Figures 8, 9 and 10 show the profiles of distributions of $\mathrm{P}$-axes and $\mathrm{T}$-axes in $\mathrm{A}, \mathrm{B}$ and $\mathrm{C}$ areas, respectively.

\subsection{Shikoku (Region A)}

In order to investigate focal mechanism solutions in the slab, we selected 50 events that occurred in the lower layer with depths from 27 to $55 \mathrm{~km}$. The stress field obtained from the solutions will be summarized as follows: the horizontal projections of P-axes lie in the NNW-SSE direction, parallel to the direction of the maximum inclination of the slab (Fig. 7). The average direction of the horizontal projections of P-axes differs about 30 degrees counterclockwisely from the relative motion of the Philippine Sea plate to the Eurasian plate, N50 ${ }^{\circ} \mathrm{W}$ (Seno et al., 1993). The horizontal projections of P-axes are nearly N-S with a little eastward component particularly beneath eastern Shikoku. The horizontal projections of T-axes are nearly E-W, parallel to the slab strike as shown in Fig. 6. Figure 8 shows the vertical profile distributions of P- and T-axes along N-S sections for area $\mathrm{A}$ in Fig. 7. The distributions of the $\mathrm{P}$ - and T-axes suggest that a stress field of down-dip compression type is dominant in the Philippine Sea slab for regions A.

\subsection{Kii peninsula (Region $B$ )}

Earthquakes with $\mathrm{M} \geqq 3.5$ were selected for the analysis of the present area. Most horizontal projections of P-axes in this area lie nearly NW-SE as shown in Figs. 5 and 7. Several $\mathrm{P}$-axes in the northern part of the present area have large E-W component, which may be affected by the westward movement of the Pacific plate, of which detailed discussion will be made elsewhere. The corresponding horizontal projections of T-axes lie nearly NE-SW (Fig. 6). Distributions of P- and T-axes of mechanism solutions of events in the profile along NNW-SSE sections in the Kii peninsula (Fig. 7B) are shown in Fig. 9. On the whole, the majority of P-axes are parallel to the dip direction of the slab, and most of their T-axes are parallel to the slab strike. Therefore, the regional intraslab stress field is characterized as down-dip compression type in the Kii peninsula, similar to that in Shikoku. Some scattered 


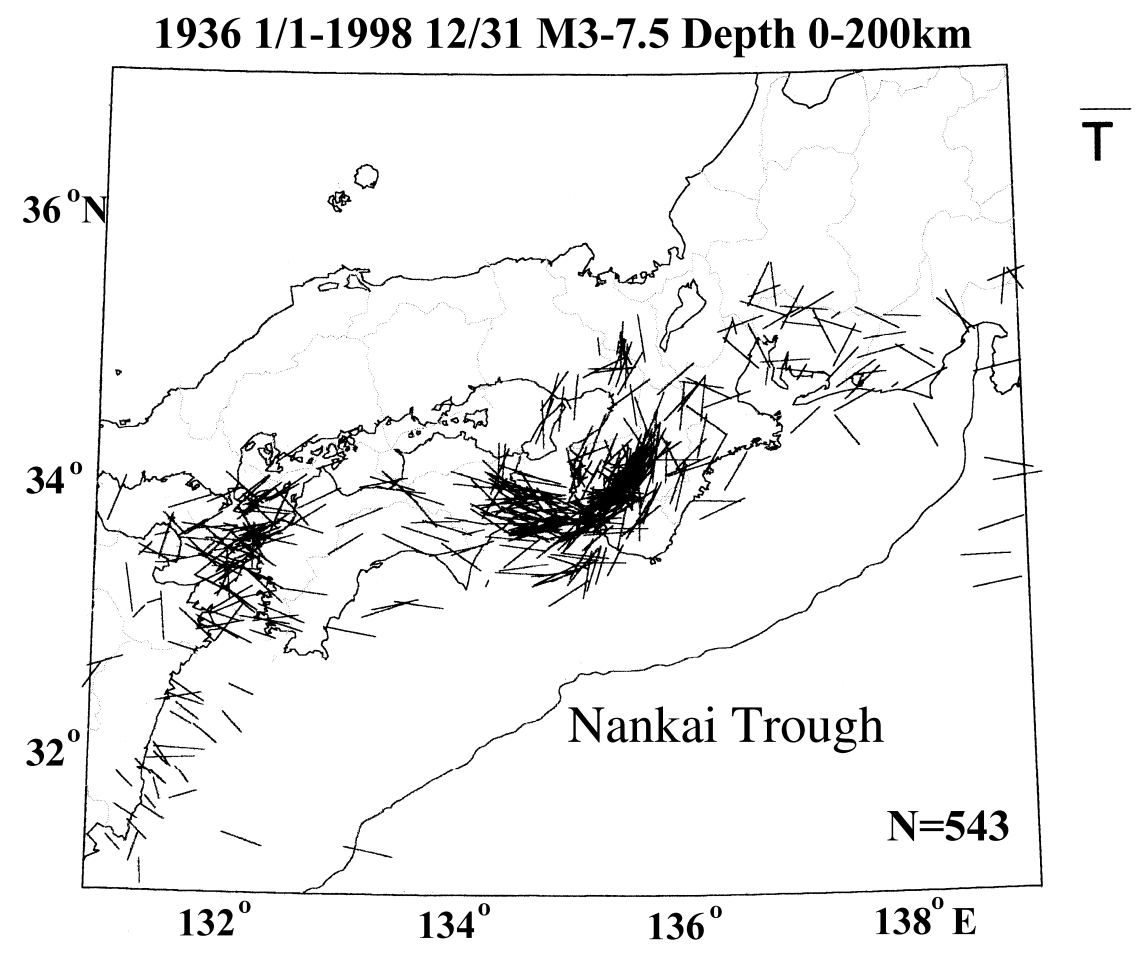

Fig. 6. Horizontal projections of extensional axes (T-axes) from focal mechanism solutions of 543 earthquakes (M $\geqq 3$ ) during $1936-1998$ in the Nankai trough.

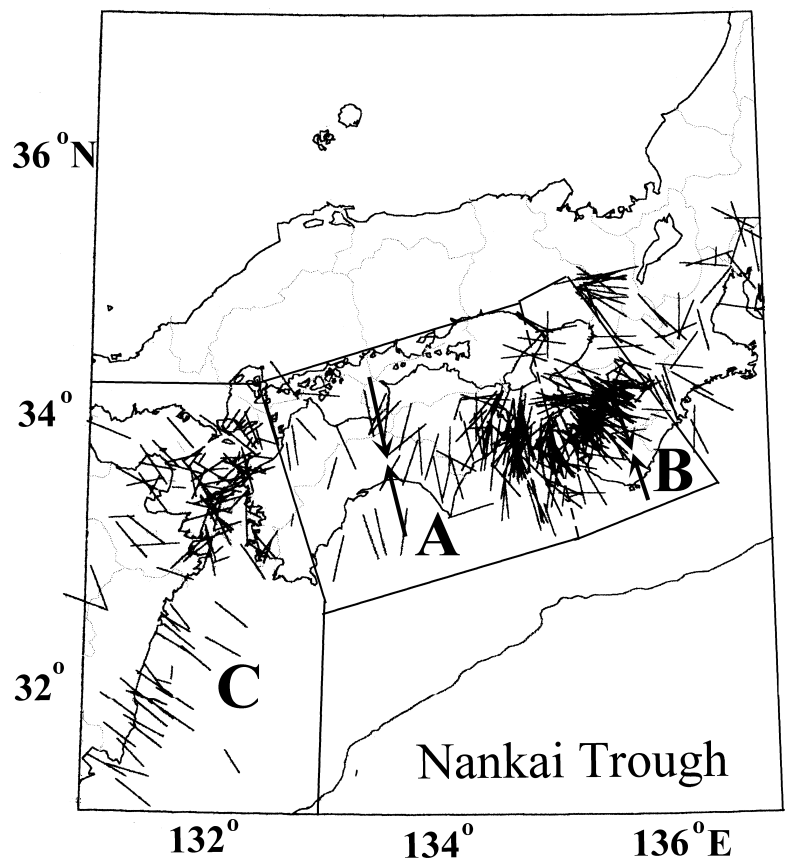

Fig. 7. Zoning in the Nankai trough for the profile analyses in Figs. 8, 9 and 10. Regions A, B and C for Shikoku, Kii and western Shikoku-Kyushu, respectively. Arrows in A and B indicate the maximum stress-axis of intraslab stress of the down-dip compression. The region $\mathrm{C}$ is of down-dip extension.

directions of both P- and T-axes can be seen in Fig. 9, which might be attributed to irregular stress field due to the abrupt bend of the slab beneath the Kii peninsula.

\subsection{From western Shikoku to Kyushu (Region C)}

This area is seismically active and events with magnitude
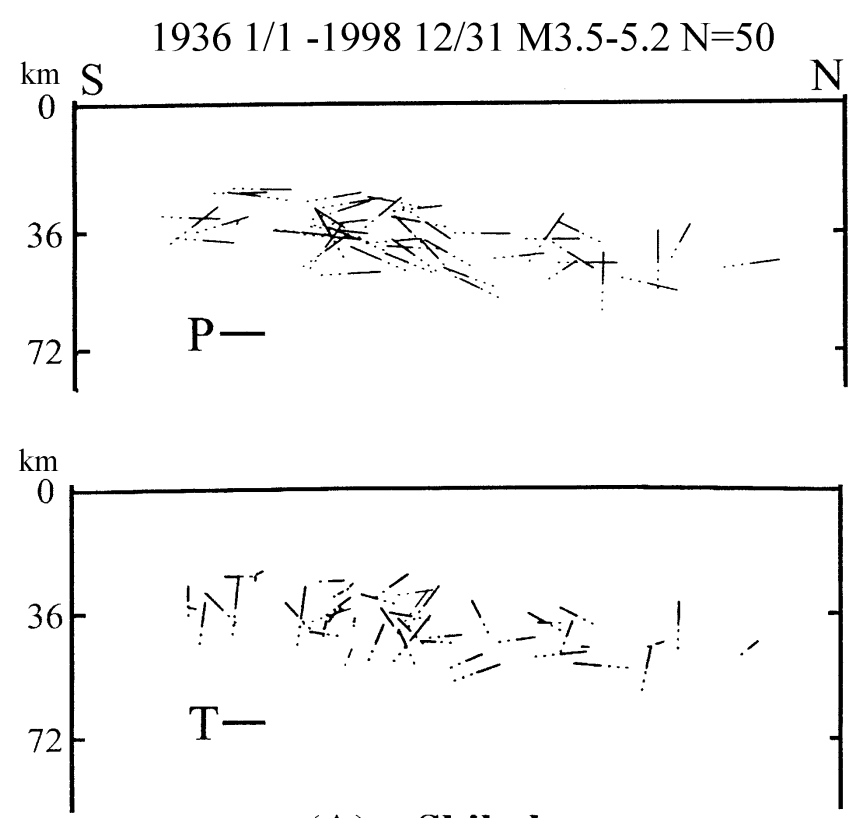

(A) Shikoku

Fig. 8. NS cross section of $\mathrm{P}$ - and T-axes beneath region A, in Fig. 7 from the western part of Shikoku to the southeastern coast of the Kii peninsular.

$(5.0<\mathrm{M}<6.0)$ occurred beneath and offshore Kyushu, for example, the earthquake of Dec. 16, 1998 (M5.6) occurred in Hyuga-nada and the Nov. 10, 1998 earthquake (M4.0) occurred in western area of Kochi. Horizontal projections of most P-axes lie NW-SE in the southern part of this region. The horizontal components of P-axes (Fig. 5 and area $\mathrm{C}$ in Fig. 7) are larger than those of T-axes on average (Fig. 6), which show that T-axes more inclined. The profiles of $\mathrm{P}$ - 

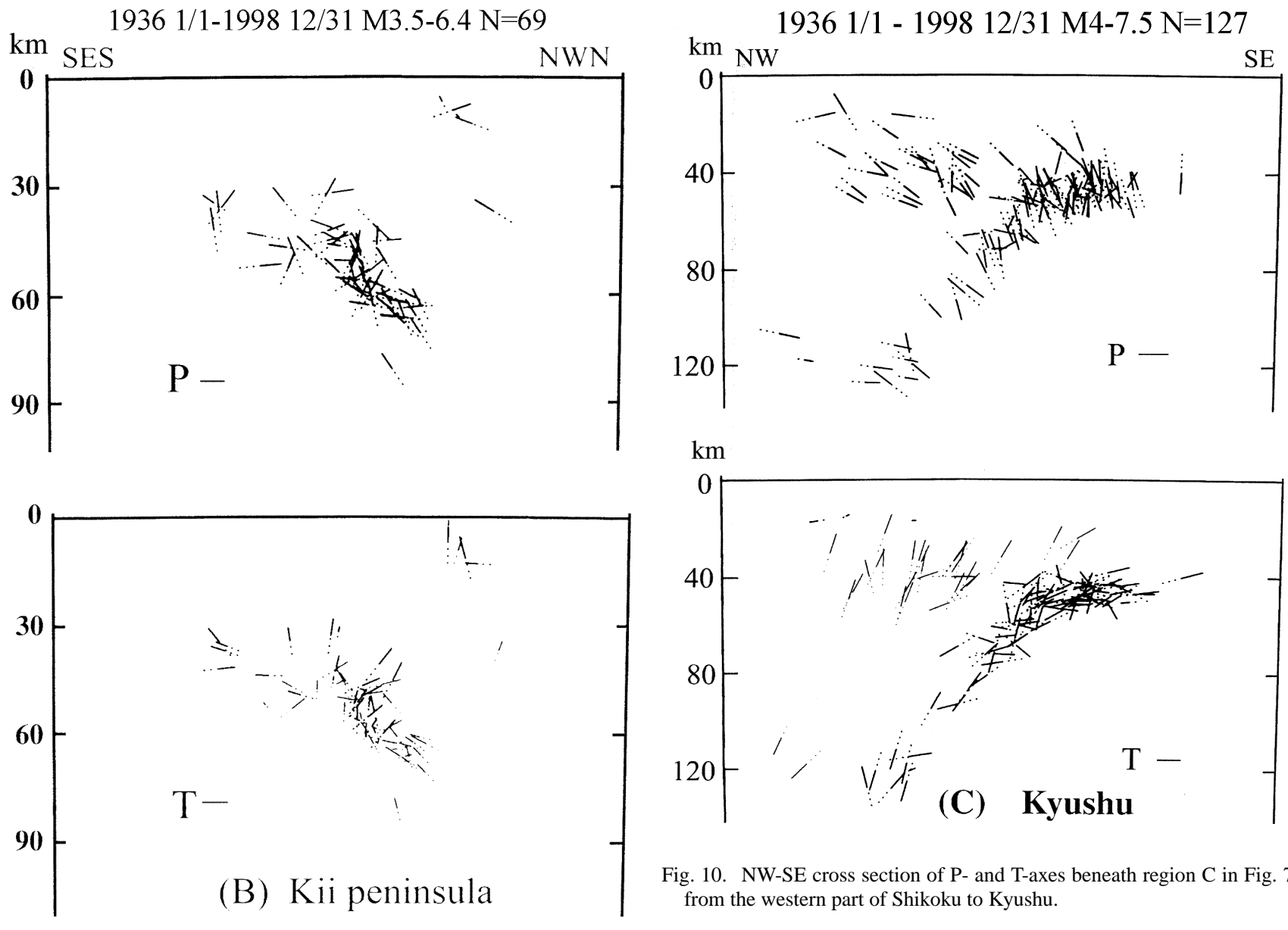

Fig. 10. NW-SE cross section of P- and T-axes beneath region $\mathrm{C}$ in Fig. 7 from the western part of Shikoku to Kyushu.

Fig. 9. SES-NWN cross section of $\mathrm{P}$ - and T-axes beneath region B in Fig. 7, the Kii peninsular $(M \geqq 3.5)$.

and T-axes along NW-SE section in this area are shown in Fig. 10. It is difficult to determine dominant directions of horizontal projections of $\mathrm{P}$ - and T-axes in the northern part of this area as shown in Figs. 5, 6 and 7. Earthquakes in the NW upper zone in Fig. 10 are events occurred in the crust. The $\mathrm{P}$-axes of focal mechanism solutions incline to the southeast with almost the same plunge. The T-axes of the most events in the Eurasian continent have a large plunge (Fig. 10). Paxes of the most events occurring in the Philippine Sea slab are perpendicular to the bending axes for both gentle-dipping and steep-dipping portions of the slab as shown in Fig. 10. Correspondingly intraslab $\mathrm{T}$-axes are almost parallel to the dip-direction (Fig. 10). It can be seen that a stress field of down-dip extension within the slab dominates the earthquake occurrence beneath the western Shikoku to Kyushu.

As mentioned above, two types of intraslab stress field exist in the Nankai trough based on the analyses of focal mechanism solutions. The stress field of down-dip compression can be seen within the slab beneath Shikoku and the Kii peninsula. However, an intraslab stress field of down-dip extension is dominant from the western Shikoku to Kyushu. The boundary between these two stress field regions runs from SSE to NNW and passes near the southwestern tip of Shikoku (see Fig. 7).

\section{Discussion}

Based on geometries of slabs and stress fields within the slabs, we will discuss the tectonic implications and slab ages in the eastern trough, Shikoku and the Kii peninsula and the western one, off Kyushu. According to geological and tectonic results, the eastern portion of the trough is a young and active convergent boundary between the Philippine Sea and Eurasian plates. The age of the Shikoku basin near the Nankai trough was estimated to be about 15-30 Ma (Kagami et al., 1987). The age of the slab in the Southwest Japan Shikoku subduction zone is about $21 \mathrm{Ma}$, much younger than that of $49 \mathrm{Ma}$ for the Ryukyu trench to the west of the Nankai trough (Jarrard, 1986).

\subsection{Geometry and slab age}

The Philippine Sea plate subducts at a shallow angle ranging from 11 to 22 degrees in eastern trough. The slab reaches to depths of 60 to $80 \mathrm{~km}$ beneath Shikoku and the Kii peninsula. However, offshore western Shikoku, the subduction angle is as large as 40 degrees, and the slab reaches to depths larger than $160 \mathrm{~km}$ beneath southern Kyushu. These features can be seen in the Benioff zones in Figs. 2 and 3. Such variations in the dip angle and depth can be attributed to variations in slab age (Wortel and Vlaar, 1978). The along-dip length of slab of the Benioff zone is proportional to the lapse time since the subduction of a slab tip started (Molnar et al., 1979). The slip velocity of the Philippine Sea plate beneath Kyushu is near $5.0 \mathrm{~cm} / \mathrm{y}$, larger than that beneath Shikoku with $4.6 \mathrm{~cm} / \mathrm{yr}$. (Seno et al., 1993). The slab at the western subduction zone is about 2 times as long as that at the east- 


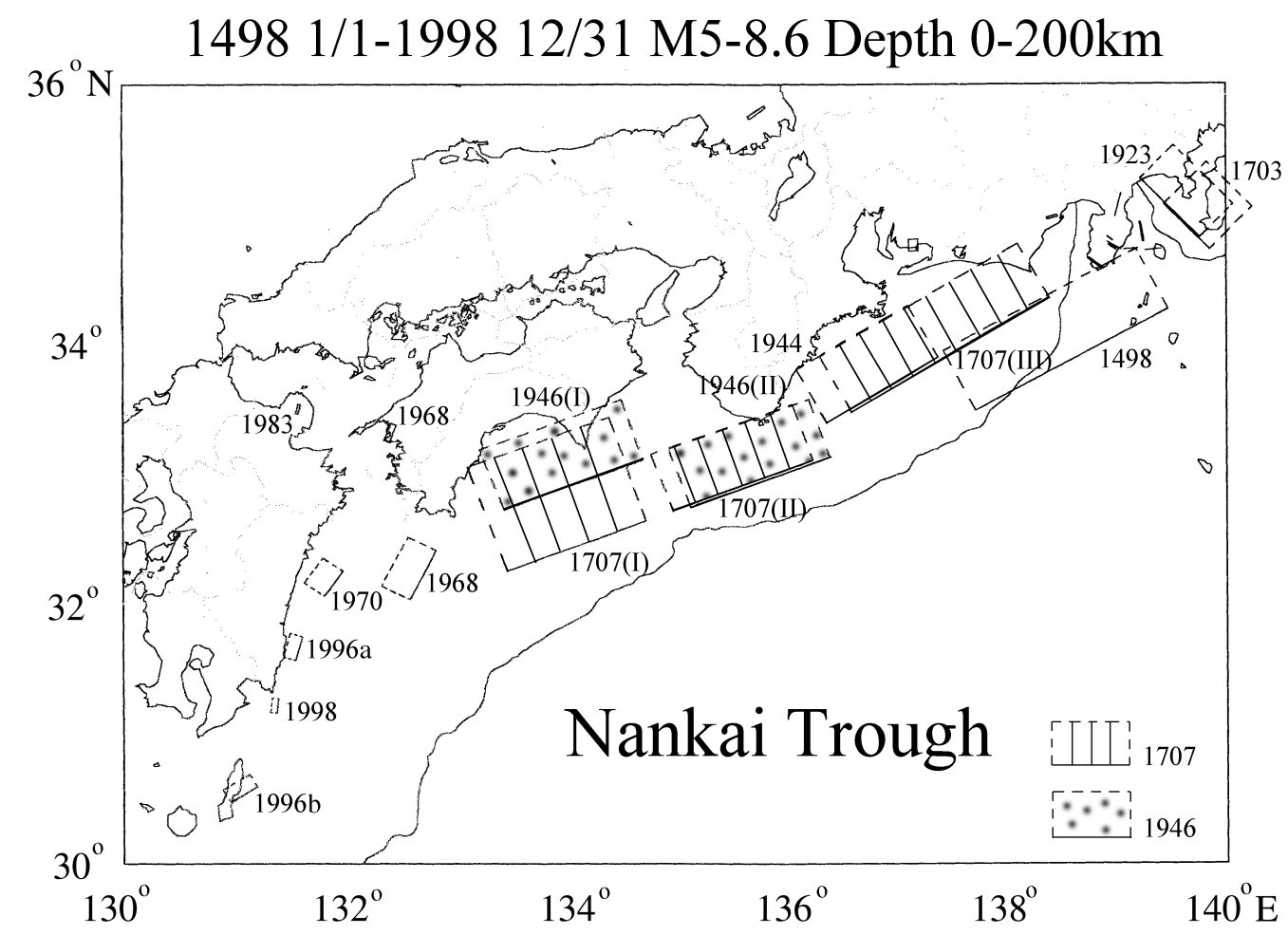

Fig. 11. Horizontal projections of fault models of large earthquakes in the Nankai trough during 1498-1998. Rectangles represent earthquake fault. Solid line of each rectangle represents the shallower side of a fault. The numeral next to the fault represents the year of event occurring. The Roman numeral in bracket next to year numeral represents the segment ordinal of the fault that has more segments. Fault Parameters of some events were referred to results compiled by Sato et al. (1995). Fault parameters of the 1498 event are from Aida (1981); the parameters of the 1707, 1944 and 1946 events are from Ando (1975, 1982); the parameters of two events occurring in 1968 and 1970 event are from Shiono et al. (1980); the parameters of the 1996a, $1996 \mathrm{~b}$ and 1998 events are from Kikuchi (2000).

ern subduction zone on the average. They are consistent with the fact that the age of the slab in the western segment of the trough is older than that of the eastern segment, being about 40 m.y.

The eastern trough is younger than the western one. The central area of the Shikoku basin may be the youngest area in the whole Philippine Sea plate. Therefore, the slab here probably is the thinnest and the depth of leading edge may be the shallowest one in the Nankai trough. The young slab with higher temperature (Hyndman et al., 1995; Kinoshita and Yamano, 1996) has higher flexibility. The curved slab geometry beneath Shikoku and the Kii area as shown in Fig. 4 may be related the flexibility. The tectonic stress field and seismicity in the region east of the Kii peninsula are strongly influenced from the Pacific plate (Zhao et al., 1997). The curved slab geometry of the subducting Philippine Sea plate beneath Shikoku and the Kii peninsula in Fig. 4 may be affected by tectonic stress due to the westward movement of the Pacific plate besides relative movement between the Philippine Sea and Eurasian plates.

\subsection{Intraslab stress field and age of slab}

Shiono (1988) pointed out that the T-axes oriented in the direction roughly parallel to the SW Japan arc, the extensional stress was predominant within the subducting slab in the direction parallel to the arc. The slab subducting beneath the SW Japan arc is probably acted by the pull from the deep slab subducting beneath the Ryukyu arc, which results in the lateral extension. Two types of intraslab stress field can be seen in the Nankai trough on the basis of the present study; we think it may be attributed to the age difference of the down-going slab between the east and west of the Nankai trough. The young oceanic plate subducts at a low angle beneath the continental plate generally as motioned by Jarrard (1986). So the oceanic plate is probably encountered resistance from the asthenosphere and high stress is accumulated; great earthquakes occur frequently on the boundary between the young oceanic and continental plates. This is similar to the states of seismicity and intraslab stress in Shikoku and the Kii peninsula obtained in the present analysis. Older oceanic plate subducts deeply into the asthenosphere at a large dip angle due to its own weight and few large events occur because of low stress (Uyeda and Kanamori, 1979). Such tectonic characteristics are very similar to those states in Kyushu.

Above characteristics are also evident from seismic activity. Figure 11 shows the horizontal projection of faults, of large earthquakes between 1498 and 1998 in the Nankai trough (Sato et al., 1995). Several fault models may be presented for some events, only one of the appropriate models is plotted in Fig. 11 because we are mainly concerned for the differences of the magnitudes, plunges, lengths and areas of faults among areas A, B and C in Fig. 7. It can be seen that the great earthquakes $(\mathrm{M}>8.0)$ having long fault with little plunges only occurred east of the southwest tip of Shikoku. It suggests that the high stress associated with the recurrence of great earthquakes only exists and accumulates in the eastern trough with intraslab stress field of down-dip compression type. The medium size events having 
short faults and great plunges occurred west of Shikoku and in Kyushu. There seems not to be accumulation of stress for great earthquakes there.

It is generally believed that great interplate earthquakes occur along the boundary with strong interplate coupling between overriding and underriding plates. Recently, many results deduced from inversion analyses of GPS (Global Positioning System) measurements indicate that strong interplate coupling exists in the Shikoku region and the Kii peninsula where the young slab subducts (Ozawa et al., 1999; Nishimura et al., 1999). Ito et al. (1999) calculated the distribution of interseismic slip accumulation in Nankai trough based on GPS data. The results indicate strong interplate coupling between the Philippine Sea and the Eurasian plates exits off Shikoku and in the Kii peninsula. The results are consistent with the stress status in the east of the trough obtained in the present study, where the intraslab stress field is of down-dip compression type and the great earthquakes occur. As to the stress field in Kyushu Seno (1998) proposed that the stress gradient might be generated by viscous drag exerted by flow spreading laterally from the mantle upwelling off Kyushu. This is consistent with the suggestion that the deep (or old) subduction generally accompanies mantle upwelling (Uyeda and Kanamori, 1979). The extensive stress field existing in a wide region from Kyushu to the Ryukyu trough, and the regular down-dip extension stress field shown in Fig. 10 may be related to the spreading flow and the deep subduction.

The reason for the variation of intraslab stress field is not exactly clear. The state of the intraslab stress depends generally on the balance of two forces, i.e. the negative buoyancy of the descending slab and the resistance force of the mantle. We think that the younger slab with a low subduction angle descends too shallowly to reach the asthenosphere, and so strong resistance force acts on the leading edge of the Philippine Sea slab. Therefore, the stress field of down-dip compression type is formed in the area from the western Shikoku to the Kii peninsula. Such a low subduction angle and large resistant are consistence with the strong coupling in the area. Sacks (1983) suggested that subduction of old lithosphere was an important driving mechanism for plate motions. The older slab descending deep reaches and enters the shallow asthenosphere in the area from the western Shikoku to Kyushu. The driving of the descending slab may play an important role and controls the stress field of intraslab; and an intraslab stress field of down-dip extension type is formed in the area from the western Shikoku to Kyushu.

\section{Conclusions}

In this study, we analyzed the regional characteristics of geometry and stress field of the slab along the Nankai trough. The main regional characteristics can be summarized as following:

(1) Beneath Shikoku, the Philippine Sea plate subducts NNW at a dip angle of about 10 degrees and its leading edge reaches down to about $60 \mathrm{~km}$ depth. Beneath the Kii peninsula, it subducts at a dip of 11 degrees in the west and at 11 to 22 degrees in the east, the leading edge reaching to about $80 \mathrm{~km}$. Beneath western Shikoku to Kyushu the Philippine Sea plate subducts NWW, changing its dip angle from 11 degrees in the north to 40 degrees in the south. The leading edge of the slab reaches to depths $60 \mathrm{~km}$ in north and to $160 \mathrm{~km}$ in the south. The slab beneath western Shikoku to Kyusyu is older than that beneath Shikoku and the Kii peninsula.

(2) Two types of stress field exist within the slab along the Nankai trough based on the focal mechanism solutions. The intraslab stress field of down-dip compression type exists in the region from the western Shikoku to the Kii peninsula. However, the stress field of down-dip extension type within the slab is dominant in the region from the western Shikoku to Kyushu, Japan. The boundary between these two stress field regions runs from SSE to NNW and passes through near the southwestern tip of Shikoku.

(3) The existence of the two types of intraslab stress field may be related to the age, depth and dip of the slab, and the interplate coupling along the Nankai trough. The younger slab with a low angle descends and a strong resistance force acts on the leading edge of the slab; a stress field of downdip compression type forms within the slab in the subduction zone from western Shikoku to the Kii peninsula. On the other hand, the older slab subducts at a greater dip and goes to $160 \mathrm{~km}$ depth in the region from the western Shikoku to Kyushu. The driving due to the old descending slab controls the intraslab stress field. Therefore, the stress field of down-dip extension type forms beneath western Shikoku to Kyushu.

Acknowledgments. The authors wish to express gratitude to Dr. H. Kinoshita of JAMSTEC for his encouragement throughout the whole research. One of authors, J. Xu is financially supported from the Japan Science and Technology Agency (STA). This study has been carried out at the Frontier Research Program for Subduction Dynamics (FRPSD) of JAMSTEC. We thank Dr. Kaneda and members of FRPSD for comments and discussions. The authors are very grateful to Dr. M. Nakamura (Tokyo Univ.) for providing valuable data. We also acknowledge Dr. Y. Ishikawa (JMA) for providing SEIS-PC software (Ishikawa and Nakamura, 1997) and the valuable discussion on data basis used in this paper. We also thank Professor L. Ruff and another anonymous reviewer for the invaluable comments. Finally, we are very grateful to Professor M. Ando, Nagoya University, Japan, for the invaluable reviews and comments to improve this paper.

\section{References}

Aida, I., Numerical simulation of historical tsunami in the Tokaido offshore region, Bull. Earthq. Res. Inst., Univ. Tokyo, 56, 367-390, 1981.

Ando, M., Source mechanisms and tectonic significance of historical earthquakes along the Nankai trough, Japan, Tectonophys., 27, 119-140, 1975

Ando, M., A fault model of the 1946 Nankaido earthquake derived from tsunami data, Phys. Earth Planet. Inter., 28, 329-336, 1982.

Ando, M., An outline: for the future Nankai earthquake, what must be done in Japan?, Chikyu Monthly, 24, 6-13, 1999.

Hirahara, K., Three-dimensional seismic structure beneath southwest Japan: the subducting Philippine Sea plate, Tectonophys., 79, 1-44, 1981.

Hori, S., H. Inoue, Y. Fukao, and M. Ukawa, Seismic detection of the untransformed 'basaltic' oceanic crust subducting into the mantle, Geophys. J. R. Astr. Soc., 83, 169-197, 1985.

Hyndman, R. D., K. Wang, and M. Yamano, Thermal constraints on the seismogenic portion of the south-western Japan subduction thrust, $J$. Geophys. Res., 100, 15373-15392, 1995.

Imamura, A., Topographical changes accompanying earthquakes or volcanic eruptions, Publ. Earthquake Invest. Comm., Foreign Languages, 25, 1-143, 1930

Imamura, A., The Hakuho Great Earthquake, Zisin, 13, 82-86, 1941 (in Japanese).

Ishibashi, K., Specification of a soon-to-occur seismic fault in the Toka 
district, Central Japan, based upon seismotectonics, Maurice Ewing, Ser. 3, 297-332, AGU, Washington D. C., 1980.

Ishikawa, Y. and K. Ishihara, The seismicity in the Philippine Sea slab beneath southwest Japan, Abstracts of 1997 Japan Earth and Planetary Science Joint meeting, No. 1, A79, 1997.

Ishikawa, Y. and K. Nakamura, SEIS-PC for Windows 95, Abstracts of 1997 Japan Earth and Planetary Science Joint Meeting, 78, 1997.

Ito, T., S. Yoshioka, and S. Miyazaki, Interplate coupling in southwest Japan deduced form inversion analysis of GPS data, Workshop on Recurrence of Great Interplate Earthquake and its Mechanism, pp. 55-56, 1999.

Jarrard, R. D., Relations among subduction parameters, Geophys. Res. Lett., 24, 217-284, 1986.

Kagami, H., K. Shiono, and A. Taira, Subducting of plate and formation of accretionary prism in Nankai trough, in Formation of Japan Islands, pp. 139-148, Iwanami Shorten Publishers, 1987.

Kamiya, S., Three-dimensional P-wave velocity structure beneath the Japanese Islands estimated from the Seismological Bulletin of the Japan Meteorological Agency, Zisin, 44(2), 185-201, 1991 (in Japanese).

Kanno, K., K. Nishi, M. Iguchi, T. Furuzawa, M. Teraishi, T. Kagiyama, M. Yamaguchi, A. Takagi, T. Kakuta, H. Ono, Y. Sudo, N. Matsuo, and H. Shimizu, A joint study of earthquake in the Kyushu region using data from the Universities' Seismic Networks, Zisin, 43, Second Series, 543545, 1990 (in Japanese).

Kikuchi, M., http://wwweic.eri.u-tokyo.ac.jp/EIC/EIC_ News/index.html, 2000.

Kimura, S. and K. Okano, The lower crust and the Moho discontinuity in Shikoku, Southwest Japan, Research Reports of Kochi University, 40, Natural Science, 49-61, 199la (in Japanese).

Kimura, S. and K. Okano, Focal depth distribution of earthquakes off Shikoku and its relation with the 1946 great Nankai earthquake, Research Reports of Kochi University, 40, Natural Science, 63-70, 1991b (in Japanese).

Kimura, S. and K. Okano, Characteristics of focal depth distribution of mantle earthquakes in the central and western part of Shikoku, Zisin, 47(2), 11-19, 1994 (in Japanese)

Kimura, S. and K. Okano, Is the oceanic crust subducting beneath Shikoku, Southwest Japan? Program and Abstracts, of 1998 Fall Meeting, the Seismological Society of Japan, C38, 1998.

Kinoshita, M. and M. Yamano, Heat flow distribution in the Nankai trough region, in Japan-Russia-China Monograph, edited by H. Tokuyama et al., pp. 77-86, Tokyo, TERRAPUB, 1996.

Kodaira, S., N. Takahashi, J. Mochizuki, M. Shinohara, and S. Kimura, The Western Nankai trough seismogenic zone: Result from wide-angle' Ocean-Bottom Seismographic survey, J. Geophys. Res., 105, 5887-5905, 2000.

Miura, K., T. Tsukuda, R. Miura, Y. Inoue, and S. Asano, Deep seismic zone in the western part of the Seto Naikai (Seto Inland Sea) and its surrounding regions, Southwestern Japan, Bull. Earthq. Res. Inst. Univ. Tokyo, 66, 553-570, 1991.

Mizoue, M., M. Nakamura, N. Seto, and Y. Ishiketa, Three-layered distribution of microearthquakes in relation to focal mechanism variation in the Kii peninsula, Southwestern Honshu, Japan, Bull. Earthq. Res. Inst. Univ. Tokyo, 58, 287-310, 1983.

Molnar, P., D. Freedman, and J. Shin, Lengths of intermediate and deep seismic zones and temperatures in down going slabs of lithosphere, Geophys. J. R. Astron. Soc., 56, 41-54, 1979.

Moores, E. M. and R. J. Twiss, Tectonics, W. H. Freeman and company, 1995.

Nakanishi, I., Precursors to ScS phases and dipping interface in the upper mantle beneath Southwestern Japan, Tectonophys., 69, 1-35, 1980.
Nakamura, M., H. Watanabe, T. Konami, S. Kimura, and K. Miura, Characteristic activities of subcrustal earthquakes along the outer zone of Southwestern Japan, Annuals of Disas. Prev. Res. Inst., Kyoto Univ., 40(B-1), 1-20, 1997.

National Astronomical Observatory, Rika Nenpyo, 788 pp., Maruzen Press, 1998.

Nishimura, S., M. Ando, and S. Miyazaki, Inter-plate Coupling along the Nankai trough and southeast-ward motion along southern part of Kyushu, Zisin, 51(2), 443-456, 1999 (in Japanese).

Okano, K., M. Nakamura, T. Konomi, and S. Kimura, Recent seismic activities along the Nankai trough off Southwest Japan in relation to major earthquakes, Mem. Fac. Sci. Kochi Univ., 4(B), 1-10, 1983.

Okano, K., S. Kimura, T. Konomi, and M. Nakamura, The Focal distribution of earthquakes in Shikoku and its surrounding regions, Zisin, 38, Second Series, 93-103, 1985 (in Japanese).

Ozawa, T., T. Tabei, and S. Miyazaki, Interplate coupling along the Nankai trough off southwest Japan derived from GPS measurements, Geophys. Res. Lett., 26, 927-930, 1999.

Sacks, I. S., The subduction of young lithosphere, J. Geophys. Res., 88, 3355-3366, 1983.

Sato, R., K. Abe, Y. Okada, K. Shimazaki, and Y. Suzuki, Parameter Handbook of Earthquake Faults, Japan, Kajima Press, 1995 (in Japanese).

Seno, T., Regional stress fields in Kyushu: Implications to deep processes, Program and abstracts of 1998 Fall Meeting, the Seismological Society of Japan, C37, 1998.

Seno, T., S. Stein, and A. E. Gripp, A model for consistent with NUVEL-1 and geological data, J. Geophys. Res., 98, 17941-17948, 1993.

Shiono, K., Seismicity of the SW Japan arc-subduction of the young Shikoku basin, Modern Geology, 12, 449-464, 1988.

Shiono, K., T. Mikumo, and Y. Ishikawa, Tectonics of the Kyushu-Ryukyu arc as evidenced from seismicity and focal mechanism of shallow to intermediate-depth earthquakes, J. Phys. Earth, 28, 17-43, 1980.

Tokyo Astronomical Observatory, List of disastrous earthquake in Japan, Rika Nenpyo, Maruzen Co. Ltd., 2000 (in Japanese).

Tsuboi, S., K. Abe, and Y. Ishikawa, Determination of fault plane solutions for small earthquakes in Japan, J. Phys. Earth, 42, 45-67, 1994.

Usami, T., Materials for Comprehensive List of Destructive Earthquakes in Japan, 416-1995, University of Tokyo Press, Tokyo, 1996 (in Japanese).

Utsu, T., Seismicity of Japan from 1885 through 1925-a new catalog of earthquakes of $\mathrm{M} \geqq 6$ felt in Japan and smaller earthquakes which caused damage in Japan-, Bull. Earthq. Res. Inst. Univ. Tokyo, 54(2), 253-308, 1979 (in Japanese).

Uyeda, S. and H. Kanamori, Back-arc opening and the mode of subduction, J. Geophys. Res., 84, 1049-1061, 1979.

Watanabe, H. and N. Maeda, Seismic activity of subcrustal earthquakes and associated tectonic properties in the southeastern part of the Kinki district, Southwestern Japan, J. Phys. Earth, 38, 325-345, 1990.

Wortel, M. J. R. and N. J. Vlaar, Age-dependent subduction of oceanic lithosphere beneath western South America, Phys. Earth Planet. Inter. 17, 201-208, 1978.

Yamazaki, F. and T. Ooida, Configuration of subducted Philippine Sea plate beneath the Chubu district, Central Japan, Zisin, 38, Second Series, 193201, 1985 (in Japanese).

Zhao, Z.-X., R. Kubota, F. Suzuki, and S. Iizuka, Crustal structure in the southern Kanto-Tokai region derived from tomographic method for seismic explosion survey, J. Phys. Earth, 45, 433-403, 1997.

J. Xu (e-mail: xujiren@ccsd.org.cn) and Y. Kono 